\title{
A monoclonal antibody raised by immunising mice with group A streptococci binds to agalactosyl IgG from rheumatoid arthritis
}

\author{
G A W ROOK,' J STEELE, ${ }^{1}$ AND T RADEMACHER ${ }^{2}$
}

From the 'Department of Medical Microbiology, University College, London and the Middlesex Hospital Medical School, Riding House Street, London; and the ${ }^{2}$ Department of Biochemistry, University of Oxford

SUMMARY It was shown recently that the IgG of patients with rheumatoid arthritis tends to lack the terminal galactose normally present on the conserved $N$-linked oligosaccharide situated on the $C_{H} 2$ domain. This results in the exposure of a terminal $N$-acetylglucosamine linked $\beta 1-2$ to mannose. It is reported here that mice immunised with the peptidoglycan/polysaccharide complex of group A streptococci can be used as a source of monoclonal antibodies binding to this epitope. It may be significant that the organism responsible for rheumatic fever evokes antibodies binding to an abnormality of $\operatorname{IgG}$ found in rheumatoid arthritis.

Key words: $N$-acetylglucosamine, peptidoglycan, $N$-linked oligosaccharide.

There is a conserved $N$-linked oligosaccharide on asparagine 297 of the $\mathrm{C}_{\mathrm{H}} 2$ domain of the $\mathrm{IgG}$ molecule. It was recently shown that the terminal galactose of this oligosaccharide tends to be absent from the IgG of patients with rheumatoid arthritis. ${ }^{1}$ The procedures used to demonstrate this are expensive and time consuming so as a first step towards the development of an immunoassay for this altered form of IgG we decided to raise monoclonal antibodies which would bind to the agalactosyl oligosaccharide, in which the terminal sugar is $\mathrm{N}$-acetylglucosamine (GlcNAc). We selected group A steptococci as the immunogen because this organism is rich in GlcNAc, has adjuvant properties, and is associated with another arthritic condition, rheumatic fever. ${ }^{2}$ These patients are known to have raised levels of antibody to GlcNAc. ${ }^{3}$ We report here that a small percentage of antiGlcNAc monoclonal antibodies raised in this way will bind to the agalactosyl oligosaccharide on the IgG from patients with rheumatoid arthritis.

\section{Materials and methods}

IMMUNISATION OF MICE

The peptidoglycan/polysaccharide complex of group

Accepted for publication 5 August 1987.

Correspondence to Dr G A W Rook, Department of Medical Microbiology, University College, London.
A streptococci was prepared as described elsewhere. ${ }^{4} \mathrm{BALB} / \mathrm{c}$ mice received two intraperitoneal injections of $50 \mu \mathrm{g}$ of this material emulsified in $0.2 \mathrm{ml}$ of incomplete Freund's adjuvant (day 0 and day 20). On day 38 they received a third intravenous dose of $50 \mu \mathrm{g}$ which was ground with squalene $(50 \mu \mathrm{g}$ of cell wall to $2 \mu \mathrm{l}$ of squalene), and then emulsified in an excess of $0.2 \%$ Tween 20 in phosphate buffered saline $(1 \mathrm{ml}$ to $10 \mu \mathrm{l}$ of squalene). Four days after this injection the spleens were harvested and fused with the JK mouse myeloma line (P3-X63-Ag8, 653) at a ratio of 10 spleen cells to one JK cell. Fusion was promoted with $50 \%(\mathrm{v} / \mathrm{v})$ polyethylene glycol (BDH No 29575, mol wt 1500) in RPMI 1640 (Gibco). The fused cells were then seeded in flat bottomed, 96 well microtitre trays at $1-3 \times 10^{5}$ cells/well in the presence of murine peritoneal cells $\left(5 \times 10^{4} /\right.$ well $)$. The medium was RPMI 1640 containing $15 \%$ fetal calf serum and $5 \%$ horse serum (Gibco), penicillin $(100 \mathrm{U} / \mathrm{ml})$, and streptomycin $(100 \mu \mathrm{g} / \mathrm{ml})$. After 48 hours $50 \%$ of the medium was replaced with double strength HAT medium, to give final concentrations of hypoxanthine $\left(10^{-4} \mathrm{~mol} / \mathrm{l}\right)$, aminopterin $\left(4 \times 10^{-7} \mathrm{~mol} / \mathrm{l}\right)$, and thymidine $\left(1.6 \times 10^{-5} \mathrm{~mol} / \mathrm{l}\right)$. Subsequently the wells were fed with fresh HAT medium every four to five days. Screening is described below. The hybridomas described here have been cloned at least three times. 
ANTIGENS FOR THE SCREENING OF MONOCLONAL ANTIBODIES

GIcNAc was conjugated to bovine serum albumin (BSA) via the diazonium derivative of $p$ aminophenyl GlcNAc (Sigma) as described by Zopf, Tsai, and Ginsburg (GlcNAc-BSA). ${ }^{5}$

Fully sialylated fetuin was purified by passage through a $5 \mu \mathrm{m}$ TSK-250 $(21.5 \times 600 \mathrm{~mm})$ gel filtration column equilibrated in $0 \cdot 1 \mathrm{M}$ potassium phosphate at $\mathrm{pH} \mathrm{7.4}$. Then to expose GicNAc residues $^{6}$ a $10 \mathrm{mg}$ aliquot of the fetuin purified by high performance liquid chromatography (HPLC) was incubated for 24 hours at $37^{\circ} \mathrm{C}$ under toluene with 10 units $/ \mathrm{ml}$ of neuraminidase from Arthrobacter ureafaciens (Boehringer Mannheim) and 6 units/ml of Jack bean $\beta$-galactosidase (purified from Jack bean meal by a modification of the method of $\mathrm{Li}$ and $\mathrm{Li}^{7}$ ) in $0.1 \mathrm{M}$ sodium acetate buffer $\mathrm{pH} \mathrm{4.0}$. The asialo-,agalactofetuin was finally purified by HPLC as described above.

Immunoglobulin enriched fractions were prepared by standard ammonium sulphate precipitation from the serum of two normal donors, and that of two donors shown to have almost exclusively agalactosyl IgG, as described previously.' To expose fully the $N$-linked sugars, and to eliminate any possible rheumatoid factor activity, these immunoglobulin preparations were then denatured in $12 \mathrm{M}$ urea with $0.5 \mathrm{M}$ 2-mercaptoethanol, and dialysed against 0.2 $\mathrm{M}$ iodoacetamide.

Supernatants were screened by an enzyme linked immunosorbent assay (ELISA). ${ }^{\circ}$ For inhibition studies the antibody was mixed with the indicated concentration of inhibitor 30 minutes before addition to antigen coated wells.

\section{Results}

MONOCLONAL ANTIBODIES BINDING TO GlcNAc-BSA AND TO ENZYME TREATED ASIALO-, AGA LACTOFETUIN

More than 200 hybridomas from the fusion produced antibodies binding to GlcNAc-BSA but not to control BSA coated wells. These were then screened for binding to the enzyme treated fetuin, with native fetuin as control. Three antibodies bound and were recloned twice for further study. The binding of one of these (GN7) to fully sialylated and enzyme treated fetuin is shown in Fig. 1.

BINDING TO IMMUNOGLOBULIN

Only the small subset of GlcNAc binding monoclonal antibodies which also bound to the enzyme treated fetuin was able to bind to agalactosyl immunoglobulin. Binding of one of these selected monoclonal antibodies (GN7) to normal and to agalactosyl immunoglobulin denatured as described? above is also shown in Fig. 1 .

SPECIFICITY OF THE MONOCLONAL

A NTI B O D I E S

Binding to the enzyme treated fetuin was reduced i the antigen coated ELISA wells were treated overnight at $37^{\circ} \mathrm{C}$ with Jack bean $\beta$ - $N$-acetyl-hexos

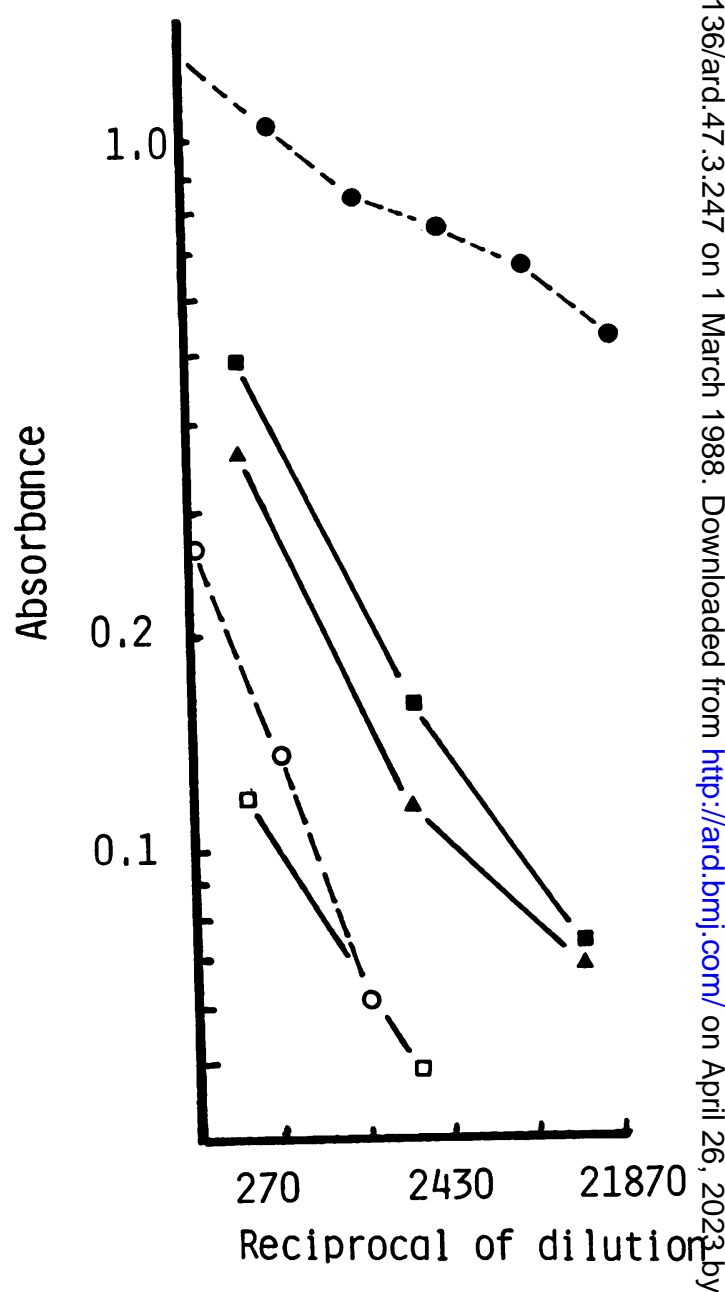

Fig. 1 Binding, assayed by ELISA, of monoclonal antibody GN7 to fully sialylated fetuin (- - --$)$, or to fetuin treated with neuraminidase and galactosidase to expose terminal GlcNAc (-- -). Also shown is the binding of the same monoclonal antibody to denatured normal immunoglobulin ( $\square$ ), and to denatured immuno-

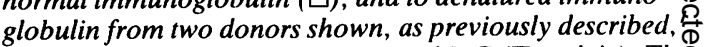
to have almost exclusively agalactosyl $\operatorname{IgG}(\mathbf{\square}$ and $\mathbf{\Delta})$. The binding to denatured immunoglobulin from other normal $\underset{<}{\sigma}$ donors is superimposable on the example shown. 


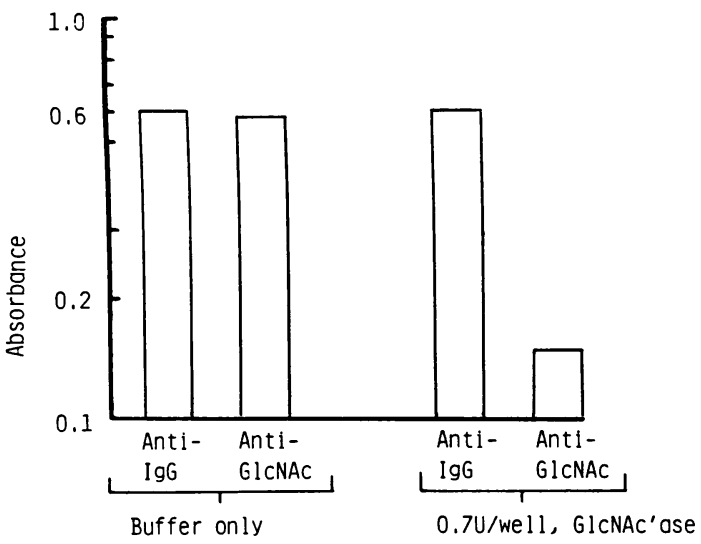

Fig. 2 Binding of monoclonal anti-GlcNAc GN7 to enzyme treated fetuin. Treatment of the coated ELISA wells with Jack bean $\beta$-hexosaminidase markedly reduced the binding of anti-GlcNAc but not of anti-IgG.

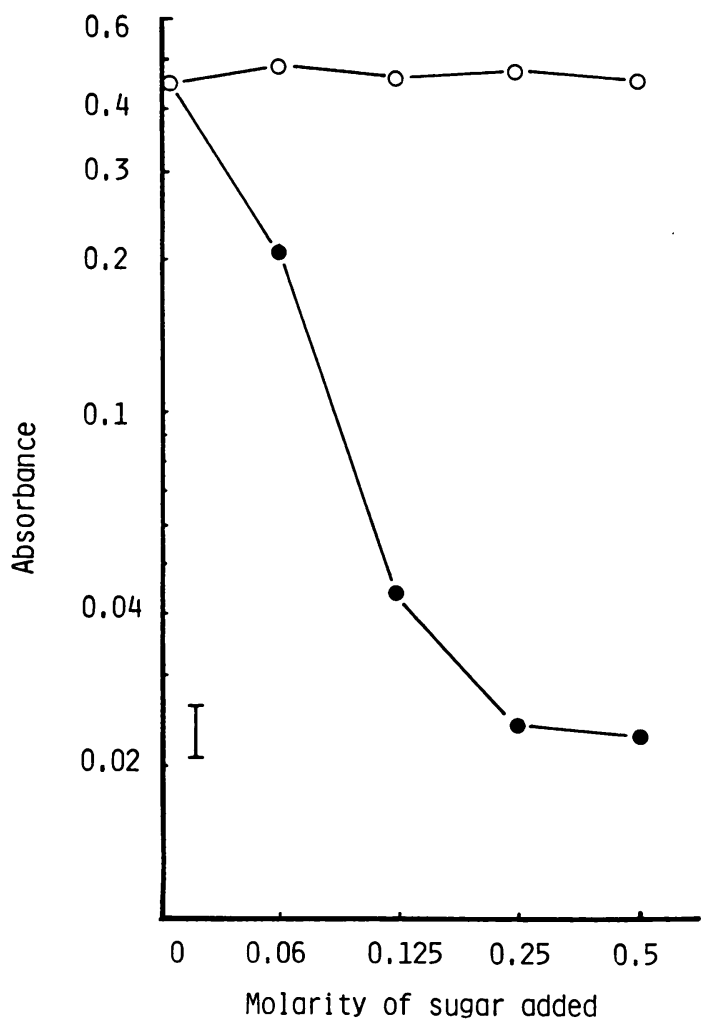

Fig. 3 Inhibition of binding of monoclonal antibody GN7 to the enzyme treated asialo-, agalactofetuin by increasing concentrations of galactose $(\mathrm{O})$ or $\mathrm{N}$-acetylglucosamine (O). The monoclonal antibody was used at a dilution of $1 / 20000$. aminidase, $0.7 \mathrm{U} /$ well, in $0.1 \mathrm{M}$ citrate buffer at $\mathrm{pH} 5 \cdot 0$, whereas incubation with the buffer alone had no effect (Fig. 2). Binding of anti-IgG to the wells was unchanged by the enzyme treatment.

Binding was also blocked by the addition of free GlcNAc, whereas galactose at the same molarity had no effect. Relatively large concentrations of GlcNAc were required, but this is not unexpected with a simple sugar (Fig. 3).

\section{Discussion}

It is thought provoking that group A streptococci, which are associated with rheumatic fever, are able to evoke formation of antibodies which will bind to an epitope on the agalactosyl IgG present in rheumatoid arthritis. It is not clear at this stage whether this is a coincidence, or whether it suggests a common pathway at some level in the pathogenesis of these two joint disorders. This point clearly deserves intensive investigation. It is already known that patients suffering from rheumatoid arthritis have raised levels of antibody, which binds to the type of streptococcal preparation used here. ${ }^{49}$

Group A streptococci have a peptidoglycan which is unusually resistant to degradation. ${ }^{2}$ Thus it may persist, and after cleavage by lysozyme which exposes GlcNAc linked $\beta 1-4$ to $\mathrm{N}$-acetylmuramic acid it may act as a longlasting stimulus for production of antibody to this sugar. Alternatively, the group A polysaccharide which is GlcNAc linked $\beta 1-3$ to polyrhamnose may be the relevant immunogen. ${ }^{2}$

Apart from their inherent interest, these antibodies appear to be suitable as one component of quantitative immunoassays for agalactosyl IgG. Such assays are now being developed.

\section{References}

1 Parekh R B, Dwck R A. Sutton B J, et al. Association of rheumatoid arthritis and primary osteoarthritis with changes in the glycosylation pattern of total serum IgG. Nature 1985; 316: 452-7.

2 Esser R E. Schwab J H, Eisenberg R A. Immunology of peptidoglycan-polysaccharide polymers from cell walls of group A streptococci. In: Stcwart-Tull D E S, Davics M. eds. Immunology of the bacterial cell envelope. New York: Wilcy, 1985: 91-118.

3 McCarty M. Further studies on the chemical basis for serological specificity of group A streptococcal carbohydratc. $J$ Exp Med 1958; 108: 311-28.

4 Johnson P M. Phua K K. Perkins H R. Hart C A. Bucknall R C. Antibody to streptococcal cell wall petidoglycan-polysaccharide polymers in seropositive and seronegative rheumatic discasc. Clin Exp Immunol 1984: 55: 115-24.

5 Zopf D A. Tsai C M, Ginsburg V. Antibodies against oligosaccharides coupled to proteins: characterisation of carbohydrate specificity by radio-immunoassay. Arch Biochem Biophys 1978: 185: 61-71.

6 Takasaki S, Kobata A. Asparaginc-linked sugar chains of 
fetuin: occurrence of tetrasialyl triantennary sugar chains containing the GalBl-3GlcNAc sequence. Biochemistry 1986; 25: $57(09-15$.

7 Li Y T. Li S-C. $\alpha$-Mannosidase, $\beta$-N-acetylhexosaminidase, and $\beta$-galactosidase from Jack bean meal. Methods Enzymol 1972; 28: $702-13$.
8 Rook G A W, Cameron H C. An inexpensive portable battery operated photometer for the reading of ELISA tests in: microtitration plates. J Immunol Methods 1981; 40: 109-14.0)

9 Johnson P M. Phua K K. Evans H B. An idiotypic complementarity between rheumatoid factor and anti-peptidoglycar antibodies. Clin Exp Imınunol 1985; 61: 373-8. 